Универзитет у Новом Саду,

Центар за родне студије АЦИМСИ, Нови Сад

DOI 10.5937/kultura1757011J

УДК 392.313/.317(=411.16)(091)

26-242-277

оригиналан научни рад

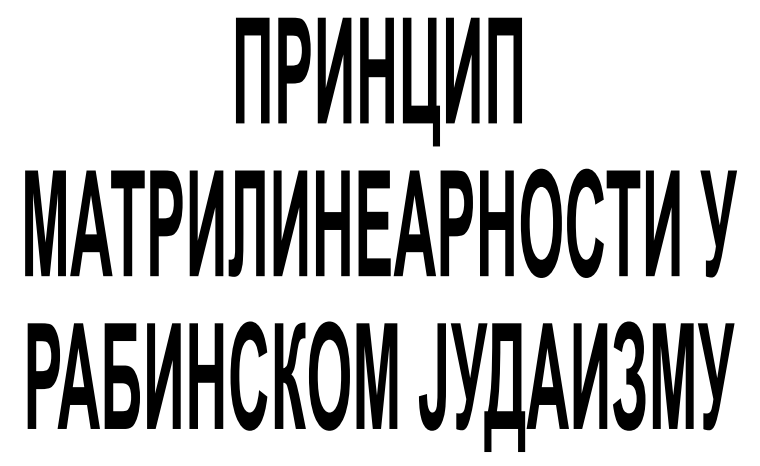

Сажетак: Матрилинераност у јудаизму представља предмет дебата, будући да још увек нема јединственог одговора на питање юеговог порекла у овој религији и разлога за инкорпорирање у праксу рабина. Фактори који су довели до појаве матрилинеарности код Јевреја несумњиво су многобројни и различити, премда сви осликавају сочио-економско стање једног друштва у конкретном историјском тренутку. Овај рад пружа увид у општа сазнања која се тичу принципа матрилинеарности у јудаизму, нудећи нека објашњења за юегово увођење од стране рабина. Кључно питање на које рад треба да одговори јесте да ли матрилинеарност код Јевреја има своје Библијско утемељење.

Кључне речи: матрилинеарност, јудаизам, Јевреји, Библија, идентитет

Опште је познато традиционално становиште јудаизма да се Јеврејином може сматрати искључиво оно лице коме је мајка Јеврејка. Сходно осетљивости и специфичности овог питања, јавља се потреба за анализирањем принципа матрилинеарности, његових корена у јудаизму и да ли оно има своје Библијско утемељење.

Према рабинском јудаизму, ${ }^{1}$ дете Јеврејина и мајке друге народности сматра се нејеврејином, односно неизраели-

1 Рабински јудаизам представљао је главни облик јудаизма од 6. века пре нове ере и кодификације вавилонског Талмуда. Заснива се на уверењу да је Мојсије од Бога добио писмену Тору на планини Синај, уз претходна усмена објашњења, позната као „усмена Тора”. Управо је концепција 
ћанином (на латинском језику: gentiles), док се дете Јеврејке и оца друге народности сматра припадником јеврејског народа. Мишна ${ }^{2}$ доноси посебан термин којим се означава лице које се због околности приликом рођења не може сматрати Јеврејином: mamzer (мушки облик) или mamzeret (женски облик). Коен (Cohen) је против превођења овог појма због специфичности хебрејског правног система. ${ }^{4}$ Са друге стране, антрополози и социолози користе термин матрилинеарност да означе друштва у којима се сродство одређује према женама, не мушкарцима. Таква друштва постојала су на подручју Старог Египта и Месопотамије, а и данас се могу наћи на просторима Африке, Индије и Полинезије. ${ }^{5}$ Премда није проучавано са аспекта савремених теорија у антропологији, рано јеврејско друштво нема карактеристике матрилинеарности уколико се пореди са друштвима Старог Египта и Месопотамије. Напротив: изузев неколико примера, рано јеврејско друштво прилично је патријархално, те је стога питање због чега су рабини усвојили принцип матрилинеарности за одређење статуса (идентитета) детета рођеног у мешовитом браку утолико значајније.

За Стари завет, односно део Библије који се односи на Јевреje, може се рећи да, гледано са хронолошког аспекта, дуго није познавао принцип матрилинеарности, тачније све до Вавилонског ропства. ${ }^{6}$ Краљеви и друге истакнуте личности неретко су женили странкиње: тако је Јуда, четврти син Јакова од Лије, оженио жену из Ханана ${ }^{7}$, Јозеф је оженио

да је Бог открио Тору у два дела, писаним и усменим путем, основа рабинског јудаизма. Видети: Neusner, J. (1975) Early Rabbinic Judaism: Historical Studies in Religion, Literature and Art, Leiden: Brill Archive, pp. 3-34.

2 Назив за прву значајнију писану редакцију усмене Торе. Састоји се од шест заповести, од којих свака садржи 7-12 трактата.

3 Оба придева, јеврејски и хебрејски, легитимно егзистирају у српском језику, с тим да се хебрејски у досадашњој пракси чешће односио на језик Старих Јевреја којим су записани Стари завет, Талмуд и други стари верски списи. Види: Одбор за стандардизацију српског језика, Одлука бp. 1, 16. 02. 1998., 25. 08. 2017., http://www.rastko.rs/filologija/odbor/odluka001.html

4 Cohen, S. (1985) The Origins of Matrilineal Principle in Rabbinic Law, AJS Review Vol.10, Cambridge: Cambridge University Press, p. 19.

5 Schneider, D. (1961) Matrilineal Kinship, Berkeley: University of California Press, pp. 7-112.

6 Истраживачи овај период најчешће означавају са pre-exilian, мисливши на прогон Јевреја и Вавилонско ропство од 597. до 538. г. п. н. е. Видети: Merriam Webster Dictionary, 15. 08. 2017., https://www.merriam-webster. com/dictionary/preexilic

7 Народ који је живео на простору Ханана често се помиње у Старом завету: да су виђени као странци, односно нејеврејски народ, доказ 
Египћанку итд. Премда је постојала забрана за Израелићане да се жене женама из Ханана, ниједан брак из периода пре Вавилонског ропства који је био склопљен са странкињом није проглашен за ништаван или неважећи. Брак је припадао приватној сфери, представљао заједницу мушкарца и жене, те се држава мало или нимало није мешала у ово подручje. ${ }^{8}$ Деца коју би странкиње родиле у браку са Израелћанима и сама су сматрана Израелћанима. Будући да у ово време не постоји идеја о прихватању јудаизма као новој вери (тзв. конверзија), Коен сматра да је склапање брака у практичном смислу било изједначено са каснијом идејом о конверзији. ${ }^{9}$ Са друге стране, Стари завет карактеришу места на којима је изражен матрилинеарни идентитет, али у сасвим другачијем контексту: јасно се даје предност деци која су рођена у браковима као званичним, легалним, заједницама у односу на децу конкубина и жена-робова. ${ }^{10}$ Приметно је да се матрилинеарни принцип користио када Израелћанка роди странцу дете, с тим да је странац у тим случајевима живео у жениној кући. То су тзв. матрилокални бракови. ${ }^{11}$

Када говоримо о Езри ${ }^{12}$, он у Јудеји уноси правне реформе у моменту када се сличан процес одвија у Атини у 5. веку пре нове ере, где Перикле под Атињанима подразумева само децу рођену од стране Атињанки које су склопиле правно валидан брак са мушкарцем из Атине. ${ }^{13}$ Езра је најпре забранио виђенијим људима Јерусалима да склапају брак са странкињама, да би након тога покушао да из заједнице искључи 113 странкиња и њихову децу. Поставља се питање због чега Езра елиминише супруге-странкиње и, нарочито, децу које су оне родиле из корпуса Израелћана. Истраживачи су се давно усагласили да су у питању далекосежне

је експлицитно навођење да су народ који треба истребити и који је и уништен од стране Јевреја. Видети: Cohen, S. (1985), p. 22.

8 Bickerman, E. (1975) La concepcion du marriage a Athenes, Bulletino dell Istituto di Diritto Romano 78, Roma: Istituto di Diritto Romano, pp.1-28.

9 Cohen, S. (1985), p. 21. Важна карактеристика конверзије јесте трансформисање религијског идентитета праћено симболичким ритуалима. Видети: Meintel, D. (2007) When There Is No Conversion: Spiritualists and Personal Religious Change, Anthropologica 49 (1), Toronto: Canadian Anthropology Society, pp. 149-162.

10 Књига постања 21:10, 22:20-24.

11 О матрилокалним браковима видети: Watermarck, E. (1922) The History of Human Marriage, New York: Allerton, pp. 296-297.

12 Премда сама Књига говори о групи Јевреја који се враћају назад у Јерусалим након Вавилонског ропства, овде се мисли на Езру као законодавца и његово виђење брачних и породичних односа.

13 Lacey, W. (1968) The Family in Classical Greece, Ithaca: Cornell University Press, pp. 100-103. 
последице које је Езра имао на уму са становиштем да ће дете које роди Јеврејка бити Јеврејин (мајка ће га васпитати у јеврејском духу), док дете странкиње никада неће бити Јеврејин. ${ }^{14}$ Мотиви за овакву забрану и уопште становиште могу се тражити и даље, али је неоспорно да је Езра унео матрилинеарни принцип међу Јевреје. Да ли је он постојао и раније, код ранијих законодаваца, или је аутентично Езрино дело, питање је на које наука још увек није дала свој коначан одговор.

Међутим, приличан је број расправа које су се тицале утицаја римског законодавства на Езру: оне настају још у 18. веку да би већ 1942. године Луј Епштајн (Louis Epstein) тврдио да је на рабински јудаизам утицало римско право. Према римском праву, могућност склапања у правном смислу препознатљивог брака (conubium, connubium) имали су искључиво грађани Рима. Брак између особе која је имала право на conubium и особе која то није (сви сем Римљана) био би валидан али не би имао важност као iustum matrimonium. Из овога следи да Римљанин, уколико ожени не-Римљанку, добија дете које неће имати право на римско грађанство; уколико добије дете са ропкињом, дете би имало статус роба. ${ }^{15}$ Међутим, разлике између римског права и дефиниција рабина нису мале и безначајне: нпр. римско право не познаје појам mamzer који Мишни није нимало стран. Важно је истаћи да римски законодавци остављају простора за исправљање грешке појединца: уколико Римљанин или Римљанка ступе у брачну заједницу са лицем које није грађанин/грађанка Рима у уверењу да оно заправо има статус грађана и притом докаже да је то учињено ненамерно, супружник/супружница и деца одмах добијају статус грађана Рима. ${ }^{16}$ Рабински јудаизам ову праксу не познаје. Како је Коен, врсни познавалац ове теме, закључио: уколико су рабини уопште писали о браку и статусу деце по рођењу под страним утицајима, онда то несумњиво може бити само римско право јер су класично грчко, хеленистичко и староегипатско у потпуности неупоредиви са рабинским јудаизмом. ${ }^{17}$

Када говоримо о Старом Риму, интересантно је образложење матрилинеарности јудаизма са аспекта утицаја римске праксе. Наиме, одређени број истраживача позивао се

\footnotetext{
14 Tscernowitz, C (1944). History of Hebrew Law, Vol.3, New York: no publisher, pp. 108-111.

15 Watson, A. (1967) The Law of Persons in the Later Roman Republic, Oxford: Clarendon Press, pp. 27-28.

16 Gnomon of the Idios Logos, §39, 46, 47.

17 Cohen, S. (1985), p. 45.
} 
на римску изреку mater certa, pater incertus, ${ }^{18}$ према којој је идентитет мајке увек био познат, док се за оца није могао поуздано утврдити. На пример, уколико жена роди дете у брачној заједници, за оца се према правном систему сматрао супруг, али је јасно да он није морао увек бити биолошки отац детета. Коен чврсто одбацује тезу да је поменута римска пракса утицала на рабине и њихово усвајање принципа матрилинеарности, наводећи да је по рабинском јудаизму искључиво отац био правно одговоран за дете. Идеја о правима мајке на дете, наслеђу детета од стране оба родитеља и слично у Европи се јавља доста касније, односно тек у 19. веку. ${ }^{19}$

Јудаизам другог храма трајао је од 530. године п. н. е. до 70. године. За овај период карактеристично је понављање изричите забране о женидби са девојкама из већ поменутог Ханана, премда аутори који припадају овом периоду, наводећи неколицину појединаца који су се оженили девојкама са овог подручја, не дају никакве коментаре на овакве бракове. ${ }^{20}$ Међутим, ова забрана се временом појачава тако да рабини почињу неговати наратив по коме сваки Израелћанин коме странкиња роди дете заправо ствара Божије непријатеље. Можда најзначајнија каракеристика овог периода јесте инсистирање рабина да странкиње, пре него што би склопиле брак са Израилћанима, морају прихватити јудаизам.

Фил, Павле и Јосиф, аутори првог века, не негују матрилинеарни принцип. Фил уводи термин nothos, али у сасвим негативном контексту. ${ }^{21}$ Под овим појмом обухватиће сву децу рођену у мешовитим браковима, без обзира да ли отац или мајка нису Јевреји. Павле сматра да један родитељ мора бити хришћанин да би дете било посвећено Христу, не истичући значај оца или мајке понаособ. ${ }^{22}$ Јосиф бележи да се линија породичне генезе губи уколико је жена свештеника (проповедника вере) нпр. силована, али не наводи ни на једном месту да странкиња која рађа Јеврејину децу заправо рађа не-Јевреје. Међутим, он јасно истиче примере

18 Изрека „мајка је увек позната, отаи не” утемељена је у римском праву са снагом praesumptio iuris et de iure, тврдећи да је отац онај на кога укаже брачна заједница, што се јасно може разликовати од очинства у биолошком смислу.

19 Cohen, S. (2001) The Matrilineal Principle in Historical Perspective, Judaism: A Quarterly Journal of Jewish Life and Thought, Michigan: Gale, Cengage Learning, p. 10.

20 Charles, R. (1913) Apocrypha and Pseudepigrapha of the Old Testament, vol. 2, Oxford: Clarendon Press, p. 182.

21 Адекватан превод био би копиле. Видети: Cohen, S. (2001), p. 28.

22 Посланица Коринћанима 7:14. 
конверзије мушкараца који су се оженили Јеврејкама, али никада не помиње обратни процес. Истраживачи се слажу да је ово резултат управо убеђења да су деца Јевреја Јевреји, без обзира на порекло и верско опредељење мајке. ${ }^{23}$

Почетком 20. века јављају се теорије према којима је матрилинеарност Јевреја заоставштина примитивних јеврејских заједница које су сродство Израелћана одређивале према мајци. Упоришта за ове теорије тражена су у Библији и Талмуду $^{24}$ али су оне ипак одбачене будући да представници истих нису уочавали разлику између појмова матрилинеарност и матријархат.

Прелаз између библијске патрилинеарности ка матрилинеарности не може се датирати пре појаве саме Мишне. Ову специфичну транзицију јесте пратио утицај идеја Старог Рима, али и схватање које се јавља и развија у 1. веку пре Христа и 1. веку нове ере да се припадницом јудаизма не сматра само жена која је удата за Јеврејина (како се у Библији помиње) већ и она над којом је извршен обредни чин водом (крштење). Матрилинеарни принцип у овом периоду јасно дефинише да женин статус у овом контексту не стоји у директној вези са одређењем мужа: уколико она сама пређе у јудаизам, њена деца су Јевреји, без обзира на то да ли је муж Јеврејин или не. Тренутно у науци постоји мишљење да не постоје конкретни докази да је матрилинеарност уведена због одређених друштвених потреба. ${ }^{25}$

Сумирајући савремена гледишта на принцип матрилинеарности у јудаизму, неопходно је рећи да је све већи број мешовитих бракова склопљених током 20. века актуелизовао проблематику националног одређивања Јевреја. Становиште караизма ${ }^{26}$ заснива се на тврдњи да се идентитет Јевреја преноси патрилинеарно, премда постоје представници који тврде да је неопходно да оба родитеља буду Јевреји. ${ }^{27}$ Са друге стране, ортодоксни јудаизам категоричан је по питању идентитета Јевреја, тврдећи да чак и ако лице промени веру током живота, оно заувек остаје Јеврејин или Јеврејка уколико се тако одређује њихова мајка. Велику пажњу шире

23 Cohen, S. (2001), pp. 28-29.

24 Aptowitzer, V. (1925) Spuren des Matriarchats im juedischen Schrifttum, Hebrew Union College Annual 4, p. 207-240.

25 Cohen, S. (1985), p. 13.

26 У питању је јеврејски верски покрет који признаје Танаха (Микру) за централну фигуру јеврејског верског права. Разликује се од становишта рабинског јудаизма који Усмену Тору, кодификовану у Талмуду, сматра једином репрезентативном интерпретацијом верских закона.

27 Њихов основни аргумент јесте навођење потомака у Тори према мушкој линији, односно патрилинеарно. 
јавности изазвао је Конзервативни покрет рабина 1986. године, који се залагао да ће сваки рабин који прихвати патрилинеарни принцип одређивања порекла бити екскомунициран, односно да се више неће сматрати рабином. Истини за вољу, овај покрет је у исто време истакао да су добродошли сви они који се „искрено осећају као Јевреји” и да се „посебна сензитивност треба показати према Јеврејима који су у мешовитим браковима и њиховим породицама". ${ }^{28}$ Треба имати на уму и да је само три године пре овог чина (1983) Централна конференција рабина Америке у својој Резолуцији истакла потребу за формалним преласком у јудаизам за све оне којима се бар један родитељ одређује као део јеврејског народа, чиме су се удаљили од традиционалног одређивања идентитета на основу мајке. ${ }^{29}$

Дебате на ову тему тренутно су заустављене помирљивим гледиштима професора Коена, који сматра да је првобитно правило одређивања идентитета било патрилинеарно, али само у случајевима када су родитељи били у правно признатој заједници (браку) или када је дете у правном смислу имало оца. Принцип матрилинеарности се у Библији у пуном обиму развија тек од другог века. ${ }^{30}$ До доба Езре, мешовити бракови не да су били забрањени, већ их је требало избегавати. Сходно томе, дете рођено у оваквој заједници у правном смислу нема оца што повлачи са собом одређивање статуса детета на основу статуса мајке, по било којој основи. Као резултат, у случајевима мешовитих бракова, који су притом забрањени, дете црпи своје јеврејско порекло од мајке: у осталим случајевима, када су оба родитеља Јевреји, статус детета се одређује по оцу, с тим да је неприпадност мајке јеврејском народу важан предуслов за последње.

\section{ЛИТЕРАТУРА:}

Aptowitzer, V. (1925) Spuren des Matriarchats im juedischen Schrifttum, Hebrew Union College Annual 4, pp. 207-240.

Bickerman, E. (1975) La concepcion du marriage a Athenes, Bulletino dell Istituto di Diritto Romano 78, Roma: Istituto di Diritto Romano, pp. 1-28.

Charles, R. (1913) Apocrypha and Pseudepigrapha of the Old Testament, vol. 2, Oxford: Clarendon Press.

28 Wertheimer J. (2002) Jews in the Center: Conservative Synagogues and their Members, New Brunswick: Rutgers University Press, pp. 195-269.

29 Reform Movement's Resolution on Patrilineal Descent, 02. 10. 2017., https:// www.jewishvirtuallibrary.org/reform-movement-s-resolution-on-patrilinealdescent-march-1983

30 Tscernowitz, C. (1944), op. cit., pp. 301-303. 


\section{КРИСТИНА ЈОРГИЋ}

Cohen, S. (1985) The Origins of Matrilineal Principle in Rabbinic Law, AJS Review Vol.10, Cambridge: Cambridge University Press.

Cohen, S. (2001) The Matrilineal Principle in Historical Perspective, Judaism: A Quarterly Journal of Jewish Life and Thought, Michigan: Gale, Cengage Learning.

Lacey, W. (1968) The Family in Classical Greece, Ithaca: Cornell University Press, pp. 100-103.

Meintel, D. (2007) When There Is No Conversion: Spiritualists and Personal Religious Change, Anthropologica 49 (1), Toronto: Canadian Anthropology Society, pp. 149-162.

Neusner, J. (1975) Early Rabbinic Judaism: Historical Studies in Religion, Literature and Art, Leiden: Brill Archive, pp. 3-34.

Schneider, D. (1961) Matrilineal Kinship, Berkeley: University of California Press, pp. 7-112.

Tscernowitz, C (1944) History of Hebrew Law, Vol. 3, New York: no publisher, pp. 108-111.

Watermarck, E. (1922) The History of Human Marriage, New York: Allerton, pp. 296-297.

Watson, A. (1967) The Law of Persons in the Later Roman Republic, Oxford: Clarendon Press, pp. 27-28.

Wertheimer J. (2002) Jews in the Center: Conservative Synagogues and their Members, New Brunswick: Rutgers University Press, pp. 195-269.

Merriam Webster Dictionary, 15. 08. 2017. https://www.merriam-webster.com/dictionary/preexilic

Reform Movement's Resolution on Patrilineal Descent, 02. 10. 2017. https://www.jewishvirtuallibrary.org/reform-movement-s-resolutionon-patrilineal-descent-march-1983

Одбор за стандардизаиију српског језика, Одлука бр.1, 16. 02. 1998., 25. 08. 2017. http://www.rastko.rs/filologija/odbor/odluka001. html 
КРИСТИНА ЈОРГИЋ

\author{
Kristina Jorgić \\ University in Novi Sad, Center for Gender Studies ACIMSI, Novi Sad
}

\title{
MATRILINEALITY IN RABBINIC JUDAISM
}

\begin{abstract}
This paper examines the origins of matrilineal principle in rabbinic Judaism and analyses the most important motives for this rabbinic practice. Despite the fact that marriage was recognized as a sensitive part of a private sphere, Ezra brought huge legal changes in Judea in the 5th century BC. He has excluded foreign wives from the corpus of Jewish people. There are still many dilemmas about the influence of the Roman legal system on Ezra, since it is clear that the matrilineal principle was introduced to Israelites at the time of Ezra. Orthodox Judaism still follows matrilineal descent. It holds that anyone with a Jewish mother also has irrevocable Jewish status; in other words, even if someone with a Jewish mother converts to another religion, that person is still considered Jewish by Jewish Law.
\end{abstract}

Key words: matrilineal, Judaism, Jews, Christian Bible, identity

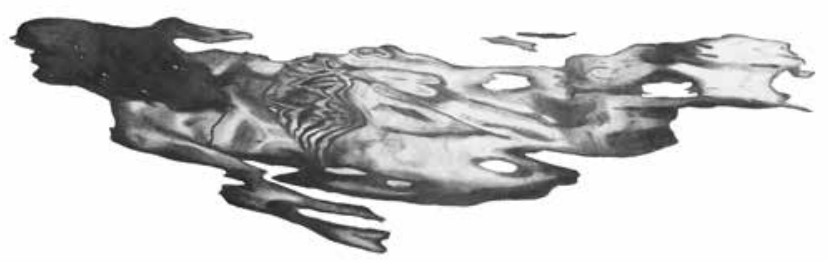

Ивана Живић, Месеи, цртеж, графитна оловка на папиру, 100 х 70 цм, 2017. 